\title{
Spermatic Feasibility after 20 Years of Freezing and Refreezing - Case Study
}

\author{
Paulo Franco Taitson ${ }^{1 *}$ and Maria do Carmo Borges de Souza $^{2}$ \\ ${ }^{1}$ Instituto de Ciências Biológicas e da Saúde; Pontifícia Universidade Católica de Minas Gerais; 30535-901; Belo \\ Horizonte - MG - Brasil. ${ }^{2}$ Instituto de Ginecologia; Universidade Federal do Rio de Janeiro; 22649-900; Rio de \\ Janeiro - RJ - Brasil
}

\begin{abstract}
The aim of the present work was to study the spermatic feasibility after 20 years of freezing, thawing and refreezing. A young man affected by testicular cancer sought the sperm freezing service. After 20 years, the samples were thawed and frozen again. After two days, thawing and analysis of the material took place. Comparison of the findings showed activity reduction from the first thawing to the fresh semen 59.09\%. For the second thawing it was $77.27 \%$. Considering the morphology, first thawing showed a reduction of $44.64 \%$ in relation to fresh semen. In the second thawing, the reduction was of $75 \%$. Spermatic motility decreased by $64.28 \%$ in relation to fresh semen and $92.85 \%$ at the level of second thawing. The patient had gone through in vitro fertilization in 2007, obtaining success in the first one attempt.
\end{abstract}

Key words: technology for freezing semen, cancer, semen storage, sperm banking

\section{INTRODUCTION}

Semen freezing techniques are known since the 18 th century through Spallanzani's works in 1776 with observations on the survival of spermatozoa after freezing. It is generally accepted, however, that Christopher Polge, Andrey Smith and Alan Parkes were the first scientists to demonstrate the possibility of using, in a reproducible way, the technology of semen cryopreservation, showing that the glycerol passessed the properties and particularities as a cryoprotectant (Polge et al., 1949). The technological development of the semen cryopreservation is based on the need of the survival of cells of spermatogenic lineage for years and, many times, for decades. Thus, the main objective is to cryopreserve man's fertilizing capacity in liquid nitrogen at $-196^{\circ} \mathrm{C}$ and to maintain its feasibility after thawing. The addition of cryoprotector solutions diminishes the damages caused to the cells due to the formation of intracellular ice crystals. The most used cryoprotectants are glycerol, dimethylsulfoxide and 1-2 propanediol (Donnelly et al., 2001). Currently, there are several cryopreservation techniques the human semen to grow and enlarge their actual value, among which the freezing prior to chemotherapy and/or radiotherapy are important. Therefore, the seminal freezing should preced chemotherapic and radiotherapic treatments

*Author for correspondence: taitson@pucminas.br 
as they usually cause aplasia in the germinative cells. The asynchrony of the reproductive activity among the patients who undergo assisted reproduction techniques determines another indication with relative incidence (Anger et al., 2003; Taitson and Souza, 2008).

\section{MATERIAL AND METHODS}

In July / 1987, a 21 year-old man affected by testicular cancer sought the sperm freezing service, considering the indication of bilateral orchiectomy and chemotherapy. The semen was mixed with $6 \%$ of glycerol and a buffer solution containing (TES) $\mathrm{N}$-tris (hydroxymethyl) methyl-2- aminoethanolsulphonic acid and TRIS (hydroxymethyl) amino methane and warmed egg yolk (v/v) and homogenized. The final solution was inserted in $0.5 \mathrm{~mL}$ straws from IMV Technologies ${ }^{\circledR}$ (L'Aigle, France). The straws were put in aluminum racks. The solution was slowly cooled in liquid nitrogen at $-80^{\circ} \mathrm{C}$ and stored in liquid nitrogen at $-196^{\circ} \mathrm{C}$.

In December / 2007, 20 years and four months after the freezing, the patient, now 41 years old, searched for the same service as he no longer needed the maintenance of the frozen semen. The patient went through in vitro fertilization with the material frozen in September 2007, obtaining success in the first one attempt. After signing the disposal authorization term, the straws were submitted to room temperature for 10 minutes to be thawed. After that, $1.0 \mathrm{~mL}$ was frozen again using the freezing medium Test Yolk Buffer (TYB) with glycerol and gentamicin from Irvine Scientific $^{\circledR}$ (Fountain Valley, USA) in 1:1 proportion. This material was sent to new cryopreservation in a liquid nitrogen. After two days, the thawing and the analysis of the material took place, assessing the feasibility of refreezing human semen using the technique of liquid nitrogen vapor.

\section{RESULTS AND DISCUSSION}

The comparison of the findings showed $59.09 \%$ activity reduction from the first thawing to the fresh semen, which was from the second thawing to the fresh semen was $77.27 \%$. Considering the morphology, the first thawing showed a reduction of $44.64 \%$ in relation to the fresh semen. In the second thawing, the reduction was $75 \%$. The spermatic motility $(\mathrm{A}+\mathrm{B})$ decreased by $64.28 \%$ in relation to the fresh semen and $92.85 \%$ at the level of the second thawing (Table 1).

Table 1 - Comparison between seminal parameters and fresh semen and post-thawing. The first thawing took place after 20 years. The second thawing occurred two days after the first.

\begin{tabular}{cccc}
\hline Parameter & Fresh semen & First thawing & Second thawing \\
\hline Activity (\%) & 44 & 18 & 10 \\
Morphology (ovals, $\%)$ & 56 & 31 & 14 \\
Motility & A: $18 \%$, B: $10 \%$ & A: $06 \%$, B: $04 \%$ & A: $00 \%$, B: $02 \%$ \\
\hline
\end{tabular}

During the cryopreservation process, the cells go through morphological alterations which can cause their death. These alterations occur at the plasmatic membrane level of the head and the intermediate piece of spermatozoa. Therefore, the preservation state of the spermatic membranes is decisive for the success of cryopreservation. The success of this technique requires the cooling rates to be in general between 10 and $50^{\circ} \mathrm{C}$ /minute (Anger et al., 2003; Neal et al., 2007). The recrystallization invariably occurs during thawing, creating intracellular ice, which is lethal (the small ice crystals are converted into few bigger crystals, when the thawing is slow). For this reason, a high rate of thawing is usually used in order to diminish the level of recrystallization. When the thawing is rapid, there is not enough time for the dehydrated cells to absorb the quantity of water the lost during freezing (Ninhaus-Silveira et al., 2006a; NinhausSilveira et al., 2006b).

In March / 2004, it was reported that a baby was born from semen frozen for 21 years and sent to the in vitro fertilization technique (Horne et al., 2004). In 2005, it was observed that semen of two individuals were frozen for 21 and 28 years and both sent to intrauterine insemination, resulting in the birth of two babies (Feldschuh et al., 2005). Another study in 2005 evaluated 238 individual semen samples collected from 34 patients (18 had cancer) between 1976 and 1989. The maximum cryopreserved sperm deposits took 21 years. All semen parameters were worse than the fresh ones 
and semen motility loss was $80 \%$. The semen deterioration criteria were more directly related to the initial freezing than to the length of storage (Bolten et al., 2005; Taitson et al., 2008).

Clarke et al (2006), studying six semen samples after more than 28 years of storage in liquid nitrogen showed recovery of human sperm motility and ability to interact with the human pellucid zone. Normal acrossomic reaction was established in four samples. A study showed that only $27 \%$ of men who stored semen prior to cancer treatment used the samples in ten years' time. Another relevant point was the fact that many of the patients that asked for semen cryopreservation were young (mean age of 24). Consequently, the beginning of the formation of their family showed be awaited (Blackhall et al., 2002).

There are reports that the semen cryopreservation and thawing can lead to damage in the seminal DNA in sterile men (Donnelly et al., 2001), but there is no data suggesting that the damage is increased by the storage period. The present study, demonstrated the post-thawing spermatic feasibility in semen frozen for 20 years that was thawed and frozen - thawed again. Refreezing of human semen by the technique of liquid nitrogen vapor allows the retrivial of viable spermatozoa after thawing. This is probably the first work to compare long time of semen criopreservation in Brazil.

\section{ACKNOWLEDGEMENTS}

The authors would like thank PUC/MG, Brazil, for the support for this work. The study is part of the pos-doctoral program from the first author.

\section{RESUMO}

Este trabalho mostra a viabilidade espermática após 20 anos de congelamento seminal, descongelamento e novo congelamento. Jovem do sexo masculino afetado por câncer testicular procurou o serviço para congelamento de espermatozóides. Após vinte anos, as amostras foram descongeladas e congeladas novamente. Após dois dias, realizou-se um novo descongelamento e análise do material. As comparações dos resultados mostraram uma redução da atividade do primeiro descongelamento ao semen fresco em 59,09\%. A partir do segundo descongelamento era de $77,27 \%$. Considerando a morfologia, o primeiro descongelamento mostrou uma redução de $44,64 \%$ em relação ao sêmen fresco. No segundo descongelamento, a redução foi de $75 \%$. A motilidade espermática diminuiu $64,28 \%$ em relação ao semen fresco e $92,85 \%$ a nível do segundo descongelamento. $\mathrm{O}$ paciente passou por fertilização in vitro em 2007, obtendo sucesso na primeira tentativa.

\section{REFERENCES}

Anger, J. T.; Gilbert, B. R.; Goldstein, M. A. R. C. (2003), Cryopreservation of sperm: Indications,methods and results. J. Urol., 170, 10791084.

Blackhall, F. H.; Atkinson, A. D.; Maaya, M. B.; Ryder, W. D. J.; Horne, G.; Brison, D. R.; Lieberman BA and Radford JA. (2002), Semen cryopreservation, utilization and reproductive outcome in men treated for Hodgkin's disease. BJC., 87, 381-384.

Bolten, M.; Weissbach, L.; Kaden, R. (2005), Cropreserved human sperm deposits: usability after decades of storage. Urology., 44, 904-908.

Clarke, G. N.; Liu, Y.; Baker, H. W. (2006), Recovery of human sperm motility and ability to interact with the human zona pellucida after more than 28 years of storage in liquid nitrogen. Fertil. Steril., 86, 721-722.

Donnelly, E. T.; Steele, E. K.; Mc Clure, N.; Lewis, S.E. (2001), Assessment of DNA integrity and morphology of ejaculated spermatozoa from fertile and infertile men before and after cryopreservation. Hum. Reprod., 16, 1191-1199.

Feldschuh, J.; Brassel, J.; Durso, N.; Levine, A. (2005), Successful sperm storage for 28 years. Fertil. Steril., 84, 1017.

Horne, G.; Atkinson, A. D.; Pease, E. H.; Logue, J. P.; Brison, D. R.; Lieberman B. A. (2004), Live birth with sperm cryopreserved for 21 years prior to cancer treatment case report. Hum. Reprod., 19, 1448-1449.

Neal, M. S.; Nagel, K.; Duckworth, J.; Bissessar, H.; Fischer, M. A.; Portwine, C.; Tozer, R.; Barr, R. D. (2007), Effectiveness of sperm banking in adolescents and young adults with cancer: a regional experience. Cancer, 110, 1125-1129.

Ninhaus-Silveira, A.; Foresti, F.; Tabata, Y. A.; Rigolino, M. G.; Veríssimo-Silveira, R. (2006a), Cryopreservation of sêmen from fuctional sexreversed genotypic females of the rainbow trout, Oncorhynchuns mykiss. Braz. arch. biol. technol., 49, 73-77. 
Ninhaus-Silveira, A.; Foresti, F.; Veríssimo-Silveira, R.; Senhorini, J. A. (2006b), Seminal analysis, cryogenic preservation, and fertility in matrinxã fish, Brycon cephalus. Braz. arch. biol. technol., 49, 651659.

Polge, C.; Smith, A. U.; Parkes, A. S. (1949), Revival of spermatozoa after vitrification and dehydration at low temperatures. Nature, 164, 666.

Taitson, P. F.; Souza, M. C. B. (2008), Incidence of male infertility by occupational factors in the state of Minas Gerais. Jornal Brasileiro de Reprodução Assistida., 12, 14-18.
Taitson, P. F.; Chami, E.; Godinho, H. P. (2008), Gene banking of the neotropical fish Leporinus elongatus: a protocol to freeze its sperm in the field. Anim. Reprod. Sci., 105, 283-291.

Received: January 28, 2008; Revised: August 14, 2008; Accepted: July 02, 2009. 